\title{
Disruption of the murine PIASx gene results in reduced testis weight
}

\author{
H Santti ${ }^{1}$, L Mikkonen ${ }^{1}$, A Anand ${ }^{1}$, S Hirvonen-Santti ${ }^{1}$, J Toppari ${ }^{3}$, M Panhuysen ${ }^{5}$,

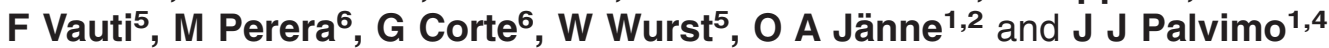 \\ ${ }^{1}$ Biomedicum Helsinki, Institute of Biomedicine, University of Helsinki, Fl-00014 Helsinki, Finland \\ ${ }^{2}$ Department of Clinical Chemistry, University of Helsinki, FI-00014 Helsinki, Finland \\ ${ }^{3}$ Departments of Physiology and Pediatrics, University of Turku, FI-20520 Turku, Finland \\ ${ }^{4}$ Department of Medical Biochemistry, University of Kuopio, FI-70211 Kuopio, Finland \\ ${ }^{5}$ Institute of Developmental Genetics, GSF-National Research Center for Environment and Health, Neuherberg, Germany \\ ${ }^{6}$ Laboratory of Gene Transfer, National Institute for Cancer Research and DOBIG, University of Genova, Genova, Italy \\ (Requests for offprints should be addressed to J J Palvimo; Email: jorma.palvimo@ helsinki.fi)
}

\begin{abstract}
PIASx belongs to the PIAS protein family, the members of which modulate activities of several transcription factors and act as E3 ligases in the sumoylation pathway. The PIASx gene is highly expressed in testis, suggesting a role in spermatogenesis. To investigate the function of PIASx in vivo, we have disrupted the PIASx gene in mice. Interestingly, the knockout mice were viable and fertile. Despite the normal fertility, the testis weight of the mutant animals was reduced and their number of apoptotic testicular cells was increased. Also, the sperm count of mutant mice tended to be reduced, but the quality of their sperm cells was normal. No significant changes were observed in the serum levels of $\mathrm{LH}$ and $\mathrm{FSH}$ or in the intratesticular testosterone concentration between the knockout animals and their wild-type littermates. Compensatory increases in other PIAS protein mRNAs were not observed in the knockout mice. These results imply that PIASx is required quantitatively rather than qualitatively for normal spermatogenesis.
\end{abstract}

Journal of Molecular Endocrinology (2005) 34, 645-654

\section{Introduction}

The PIAS (protein inhibitor of activated STAT (signal transducer and activator of transcription)) protein family consists of at least six members in mammals: PIAS1, PIAS3 and its longer splice variant PIAS3L, PIASy, and the $\alpha$ and $\beta$ splice variants of PIASx (Nakagawa \& Yokosawa 2002, Schmidt \& Müller 2003). PIAS proteins show predominantly nuclear localization and are characterized by an N-terminal SAP (scaffold attachment factor, acinus, and PIAS) and a C-terminal SP-RING domain (Schmidt \& Müller 2003). PIAS proteins were first identified as inhibitors of activated STAT (Chung et al. 1997), but they have thereafter been shown to interact with and modulate several other proteins, such as steroid receptors and p53 (Schmidt \& Müller 2003). Recently, PIAS proteins have been shown to act as E3 ligases in sumoylation (Melchior et al. 2003), but they also appear to possess functions beyond the modification process of sumoylation.

Sumoylation is a posttranslational modification resembling ubiquitination, where a SUMO (small ubiquitin-related modifier) protein is attached to a lysine residue of a target protein. Several consequences for sumoylation have been found. Sumoylation may block ubiquitination at the same lysine residue and thereby prevent degradation of a target protein such as $І \kappa B \alpha$ (inhibitor of nuclear factor $\kappa \mathrm{B}$ alpha) or PCNA (proliferating cell nuclear antigen; Desterro et al. 1998, Hoege et al. 2002). Sumoylation also plays a role in nuclear import and export as well as in the regulation of subnuclear localization of a number of proteins (Melchior et al. 2003, Seeler \& Dejean 2003). Many of the sumoylation targets are transcription factors, and sumoylation may regulate their transcriptional activity (Verger et al. 2003). Mammals possess three different SUMO proteins; SUMO-1 and the nearly identical SUMO-2 and SUMO-3 (Seeler \& Dejean 2003). E1-activating enzyme Aos1/Uba2 and E2-conjugating enzyme Ubc9 are needed for the attachment of SUMOs to target proteins (Seeler \& Dejean 2003), and SUMO E3 ligases appear to facilitate the reaction. In addition to PIAS proteins, nucleoporin RanBP2 and polycomb protein Pc2 have been shown to possess SUMO E3 ligase activity (Pichler et al. 2002, Kagey et al. 2003).

In Saccharomyces cerevisiae, PIAS protein family consists of Sizl and Siz2. Deletion of either Siz1 or Siz2 leads to reduced levels of SUMO conjugates, and the compound 
mutant shows retarded growth and a delay or arrest in the cell cycle (Johnson \& Gupta 2001). In Drosophila melanogaster, only one PIAS gene, termed dPIAS/Zimp/ $\mathrm{Su}(\mathrm{var}) 2-10$, is currently known. It is an essential gene; cells in which dPIAS is mutated show severe abnormalities in chromosome condensation and segregation (Mohr \& Boswell 1999, Betz et al. 2001, Hari et al. 2001).

PIASx is highly expressed in testis, and the protein can be detected in spermatogonia and pachytene spermatocytes up to stage XII of the seminiferous epithelium as well as in Sertoli cells, suggesting that PIASx has a role in testicular function (Moilanen et al. 1999, Yan et al. 2003). We have disrupted the PIASx gene in a large-scale gene-trap mutagenesis of the mouse genome (Hansen et al. 2003). The preliminary analysis of PIASx gene-targeted mice, however, did not reveal an obvious phenotype (Hansen et al. 2003). In this study, we have examined in more detail the consequences of PIASx deficiency on testicular function. We show that homozygote PIASx mutants display a reduction in testis size although their fertility is normal.

\section{Materials and methods}

\section{PIASx mutant mice}

The production of the PIASx-knockout mouse has been described before (Wiles et al. 2000, Hansen et al. 2003). Briefly, ES (embryonic stem) cells were electroporated with PT1ßgeo gene-trap vector (Wiles et al. 2000), which contains an En-2 splice acceptor site upstream of a $\beta$-galactosidase/neomycin-resistance fusion gene ( $\beta$ geo). Gene-trap vector integration occurred in the second intron of the PIASx gene as determined by sequencing of the fusion transcript, PCR, and Northern- and Southern-blot analyses (Fig. 1 and results not shown). Genotyping of mice was performed using genomic DNA from a tail-clip biopsy by using PCR with sense primer 5'-GTTCTCATCAAGCGCACGAG-3' and antisense primers 5'-CTAGACATTCATACTCTCAGGTC-3' and 5 '-CTTGAAGGACTCGAATAGGGTA-3' for wild-type and mutant alleles, respectively. Mice were backcrossed with G57BL/6 mice for several generations. All animal experiments were approved by the Institutional Review Board on animal experiments at the University of Helsinki. Mice were analyzed at the age of 3 months if not specified otherwise. The wild-type control animals were either littermates or other wild-type mice with the same genetic background and housing conditions.

\section{Sperm counts}

Cauda epididymis was excised from 3-month-old mice and pierced with a 25-gauge needle in a cell-culture dish containing $0.5 \mathrm{ml}$ Brinster's BMOC-3 medium (Invitrogen, Carlsbad, CA, USA). Sperm suspensions were incubated at $37{ }^{\circ} \mathrm{C}$ in a humidified $5 \% \mathrm{CO}_{2} / 95 \%$ air environment for $30 \mathrm{~min}$. Sperm suspensions were diluted $1: 10$ in the medium and sperm counts were determined using a hemocytometer. Sperm count is expressed as the number of sperm cells per epididymis.

\section{Acridine Orange staining}

Spermatozoa from cauda epididymides were obtained by placing a piece of cauda epididymis in a drop of Tris-buffered saline (TBS; $100 \mathrm{mM}$ Tris/HCl and $150 \mathrm{mM} \mathrm{NaCl}, \mathrm{pH} 7 \cdot 5$ ) and squeezing with forceps. Spermatozoa were smeared on glass slides, air-dried, fixed with acetic alcohol (1:3, v/v, glacial acetic acid/methanol) for $2 \mathrm{~h}$, and air-dried again. Slides were stained for $5 \mathrm{~min}$ in a solution containing 0.02\% Acridine Orange (Sigma-Aldrich, Steinheim, Germany) in a citrate/phosphate buffer $(\mathrm{pH} 2 \cdot 5$ ) protected from light. Slides were rinsed with deionized water, covered with a coverslip, and sealed with Permount (Fisher Scientific, Fairlawn, NJ, USA). Slides were kept in the dark and examined using an Olympus AX70 fluorescence microscope (Olympus, Tokyo, Japan) with $490 \mathrm{~nm}$ excitation filter and $530 \mathrm{~nm}$ barrier. Spermatozoa with normal DNA structure displayed a green fluorescent color, whereas yellow to red marked abnormal DNA structure.

\section{Hormone measurements}

Blood was collected by cardiac puncture with a 25-gauge needle, was allowed to clot for at least $30 \mathrm{~min}$, and then centrifuged for $10 \mathrm{~min}$ at $1000 \mathrm{~g}$. Serum luteinizing hormone ( $\mathrm{LH})$ and follicle-stimulating hormone $(\mathrm{FSH})$ levels were determined by immunofluorometric assays as described previously (Haavisto et al. 1993, van Casteren et al. 2000). Intratesticular testosterone was determined by homogenizing approximately half of a testis in $0.5 \mathrm{ml}$ PBS $(4.3 \mathrm{mM}$ sodium phosphate, $1.4 \mathrm{mM}$ potassium phosphate, $137 \mathrm{mM} \mathrm{NaCl}$, and $2 \cdot 7 \mathrm{mM} \mathrm{KCl}$, pH 7.3). $300 \mu \mathrm{l}$ of the gonadal homogenate was extracted twice with $2 \mathrm{ml}$ diethyl ether and evaporated to dryness over night. After reconstitution into $200 \mu \mathrm{l}$ PBS, testosterone was measured by standard RIA (Huhtaniemi et al. 1985). Protein concentration in homogenates was measured using the Bradford method (Bradford 1976), and testosterone concentration was related to protein concentration.

\section{Histological examination}

Testes were immersed in Bouin's fixative overnight at $4{ }^{\circ} \mathrm{C}$, embedded in paraffin, and sectioned at $5 \mu \mathrm{m}$ thickness. Sections were mounted on poly-lysine-coated 
A

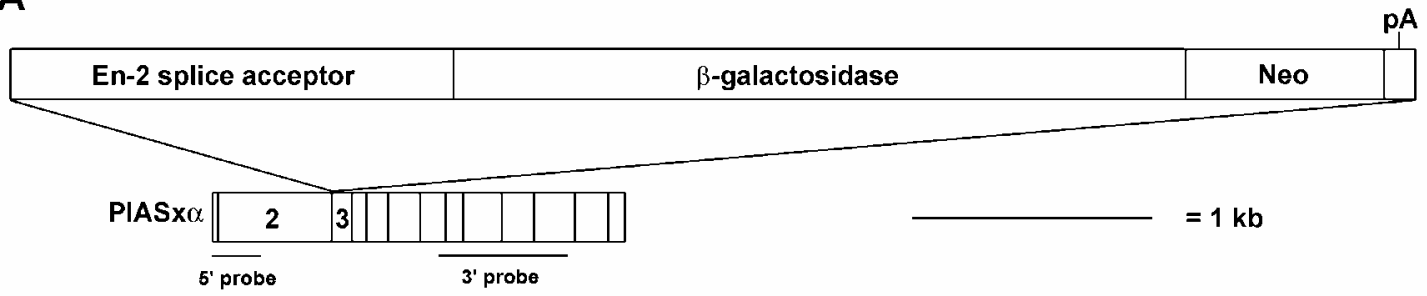

B

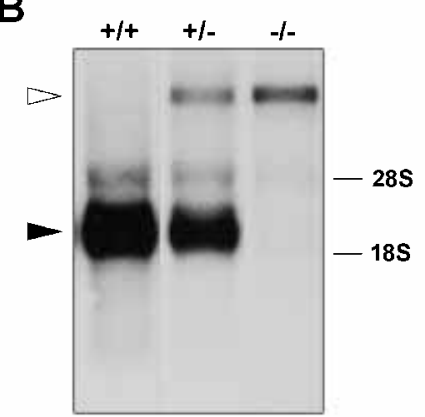

5 probe

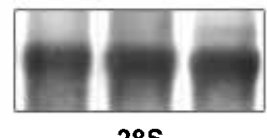

C

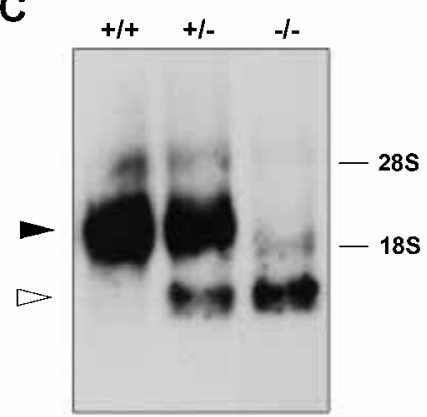

3' probe

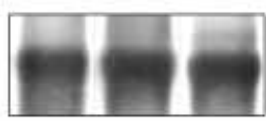

285

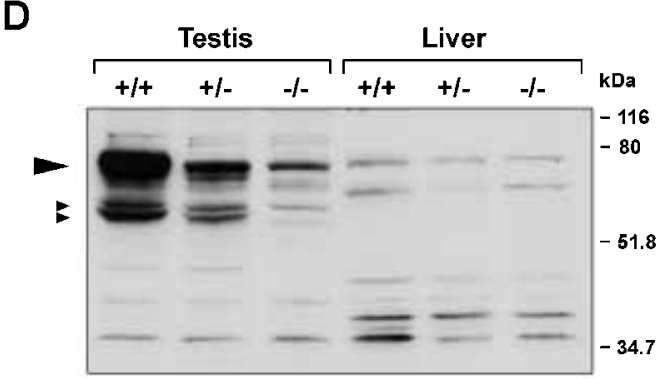

PIASx

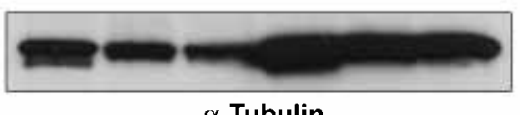

$\alpha-$ Tubulin

Figure 1 Generation of PIASx mutant mice. (A) Schematic representation of the gene-trap vector PT1 $\beta$ geo and insertion site. The gene-trap vector is inserted into the second intron of the PIASx gene resulting in a fusion transcript containing exons 1 and 2 of the truncated PIASx mRNA and $\beta$ geo mRNA. (B) Northern-blot analysis of PIASx transcripts in PIASx ${ }^{+/+}, \mathrm{PIASx}^{+/-}$, and PIASx ${ }^{-/-}$ mice. Northern blots of testicular total RNA were hybridized with a probe that recognizes the second exon of the PIASx wild-type $(+/+)$ and mutant $(-/-)$ fusion transcript. Open arrowhead, fusion mRNA between the $5^{\prime}$ part of the PIASx transcript and the $\beta$ geo transcript. Solid arrowhead, authentic PIASx mRNA. Equal loading of RNA was verified by hybridization with a probe specific for 28 S rRNA. (C) Northern-blot analysis of PIASx transcripts in PIASx ${ }^{+/+}$, PIASx ${ }^{+/-}$, and PIASx ${ }^{-1-}$ mice. Northern blots of testicular total RNA were hybridized with a probe that recognizes exons 7-11 of the PIASx wild-type transcript. Solid arrowhead, authentic PIASx mRNA. Open arrowhead, a shorter form of the PIASx transcript that is present in PIASx ${ }^{+/-}$and PIASx ${ }^{-/-}$mice. Equal loading of RNA was verified as for (B). (D) Immunoblot analysis of testicular and liver protein extracts in PIASx ${ }^{+/+}$, PIASx ${ }^{+/-}$, and $\mathrm{PIASx}^{-/-}$mice. PIASx was detected with a polyclonal anti-ARIP3 antibody (Moilanen et al. 1999). The antibody crossreacts to some extent with PIAS1 and PIAS3, and it is therefore likely that the weak band remaining at about the position of PIASx (large arrowhead) in the PIASx ${ }^{-1-}$ mice corresponds to PIAS1 or PIAS3 that show similar migration in SDS/PAGE (see Kotaja et al. 2000). Note that a similar weak signal is also present in the liver extracts, but its intensity does not differ between the wild-type and knockout mice, indicating that the weak signal is most likely derived from PIAS proteins other than PIASx. Small arrowheads, shorter forms of PIASx protein that are probably a result of proteolysis. Comparable loading of protein was verified with anti- $\alpha$-tubulin antibody.

slides, stained with hematoxylin and eosin, and examined with light microscope. Diameter of seminiferous tubules was measured from tubules at stage VII-VIII of the seminiferous epithelial cycle with the help of a scale bar.

\section{TUNEL (terminal deoxynucleotidyl transferase-mediated dUTP-biotin nick-end labelling) staining}

Testes were fixed in $4 \%$ paraformaldehyde, embedded in paraffin, and sectioned at $5 \mu \mathrm{m}$ thickness. Sections were mounted on poly-lysine-coated slides and TUNEL staining was performed with the DeadEnd colorimetric
TUNEL system (Promega, Madison, WI, USA) according to the manufacturer's instructions. The numbers of TUNEL-positive cells and seminiferous tubules were counted from four sections and the number of apoptotic cells was expressed in terms of cells per 100 tubules.

\section{Northern blotting}

Probe templates for PIASx were PCR-amplified from testicular cDNA using the following oligonucleotides: upstream of gene-trap insertion, 5'-AAATGGGGGA TTTCGAGGAGTTG-3' (nucleotides 188-210 of NM_008602.2) and 5'-TGTGGGTGGGTATCGGC GTCT-3' (nucleotides 393-373 of NM_008602-2); 
downstream of gene-trap insertion, 5'-ATGAAAGG TATTAGAAATCGTGATCATTCG-3' (nucleotides 1117-1146 of NM_008602.2) and 5'-TGGTTTTGG CGGGAGGGTCTT-3' (nucleotides 1654-1634 of NM_008602-2). The oligonucleotides that were used in construction of the probe templates for PIAS1, PIAS3, PIASy, and Pem are shown in Supplementary data table 1 (see http://jme.endocrinology-journals.org/content/ vol34/issue3/). The amplified products were cloned into pGEM-T Easy vector (Promega) and the resulting insert was verified by sequencing. The plasmids were linearized and antisense RNA probes were prepared using either SP6 or T7 RNA polymerase (Promega). $\left[\alpha-{ }^{32} \mathrm{P}\right] \mathrm{UTP}$ (Amersham Biosciences) was used for labeling of the antisense probe. $28 \mathrm{~S}$ rRNA cDNA probe was labeled with $\left[\alpha-{ }^{32} \mathrm{P}\right] \mathrm{dCTP}$ (Amersham Biosciences) by the random-priming method (Ready-To-Go DNA Labeling Beads; Amersham Biosciences). Total RNA was isolated from testes using Trizol reagent (Invitrogen) according to the manufacturer's instructions. $10 \mu \mathrm{g}$ of total RNA were size-fractionated in $1 \%$ denaturing agarose gel and transferred on to Hybond-N+ nylon membrane (Amersham Biosciences). Prehybridization and hybridization were performed with ULTRAhyb (Ambion, Austin, TX, USA) according to the manufacturer's instructions.

\section{Immunoblot analysis}

Mouse tissues were homogenized in a buffer containing $50 \mathrm{mM}$ Tris/HCl, pH 7.8, $300 \mathrm{mM} \mathrm{NaCl}, 5 \mathrm{mM}$ EDTA, 1\% Nonidet P-40, and a 1:100 dilution of protease-inhibitor cocktail (Sigma-Aldrich). The tissue lysates were centrifuged at $16000 \mathrm{~g}$ for $20 \mathrm{~min}$ at $4{ }^{\circ} \mathrm{C}$, the supernatants were transferred to new tubes, and the concentration of protein was measured using the Bradford method (Bradford 1976). Samples from the supernatants $(50 \mu \mathrm{g}$ protein/lane) were resolved on SDS-PAGE and electrophoretically transferred on to nitrocellulose membranes (Hybond EGL; Amersham Biosciences). The membrane was blocked and washed according to the instructions of the manufacturer (Amersham Biosciences). PIASx protein was detected with a polyclonal rabbit anti-ARIP3 antibody (1:5000 dilution; Moilanen et al. 1999). The immunocomplexes were visualized with horseradish peroxidase-conjugated goat anti-rabbit IgG antibody (1:10 000 dilution; Zymed Laboratories, South San Francisco, CA, USA) and the ECL detection system (Amersham Biosciences). Mouse anti- $\alpha$-tubulin monoclonal antibody (sc-5286; Santa Cruz Biotechnology, Santa Cruz, CA, USA) was used to monitor sample loading.

\section{Microarray analysis}

Total RNA was isolated from testes of three mutant and three wild-type mice with Trizol reagent and the
RNeasy kit (Qiagen, Hilden, Germany) according to manufacturers' instructions. $20 \mu \mathrm{g}$ total RNA was labeled with Cy3-dUTP (wild-type) and Cy5-dUTP (mutant) using the Fluorescent Direct Label kit (Agilent Technologies, Palo Alto, CA, USA) according to the manufacturer's instructions. cDNAs were subsequently hybridized on Mouse (Development) Oligo Array slides (Agilent Technologies) representing over 20000 known mouse genes. The fluorescence intensities on the slides were analyzed using a laser confocal scanner and Feature Extraction Software (Agilent Technologies). Low-quality measurements (i.e. the signal was lower than $2 \cdot 6$ times the background, more than $50 \%$ of pixels of the spot were saturated, or either the spot or the background were not uniform) were excluded from the analysis. After background subtraction, the ratio was calculated by dividing the average intensity of each spot in mutant hybridization by the average intensity of the corresponding spot in the wild-type hybridization. For transcripts with two or three high-quality measurements from separate slides, the mean of log-transformed ratios was calculated. Transcripts that corresponded to a Unigene cluster, had a mean of log-transformed ratios below -0.3 (-2-fold-change) or above 0.3 (2-fold change), and differed significantly from zero $(P<0.05$ as assessed with $t$-test) were regarded as differentially expressed.

\section{RT (reverse transcriptase)-PCR}

$3 \mu \mathrm{g}$ total RNA (three wild-type and three mutant testes) and 50 ng oligo(dT) $)_{12-18}$ primer (Amersham Biosciences) were heated to $70{ }^{\circ} \mathrm{C}$ for $10 \mathrm{~min}$. cDNA synthesis was carried out with $9 \mathrm{U}$ AMV (avian myeloblastosis virus) RT (Promega) at $50{ }^{\circ} \mathrm{C}$ for $1 \mathrm{~h}$ and subsequently at $42{ }^{\circ} \mathrm{C}$ for $1 \mathrm{~h}$. PCRs were performed with the Lightcycler system using SYBR Green I dye (Roche Molecular Systems, Indianapolis, IN, USA; Wittwer et al. 1997). Thermocycling was carried out in a final volume of $20 \mu \mathrm{l}$, containing $2 \mu \mathrm{l}$ cDNA sample (1:50-100 dilution) or standard cDNA, $3.5 \mathrm{mM} \mathrm{MgCl}_{2}$, $0.5 \mu \mathrm{M}$ primers, and $2 \mu \mathrm{l}$ FastStart DNA master SYBR Green I mix. After a 10-min initial denaturation at $95^{\circ} \mathrm{C}$, the 45 -cycle run consisted of a 10 -s denaturation step and a 5-s annealing step followed by an extension step at $72{ }^{\circ} \mathrm{C}$. Annealing temperatures, extension times, melting temperatures, and oligomers that were used in RT-PGR are shown in Supplementary data table 1 (see http://jme.endocrinology-journals.org/content/ vol34/issue3/). A standard curve for PCR test was constructed using serial 1:5 dilutions of normal murine testis cDNA. The concentrations of samples, analyzed in triplicate, were determined with the help of standard curve using the fit-points method in data-analysis software (Wittwer et al. 1997, Woo et al. 1998). The mean of two repeated PCR values was used in the 
Table 1 Body weight, testis weights, and epididymal sperm count of wild-type and mutant male mice. Values are means \pm S.E.M. from 14 animals

\begin{tabular}{|c|c|c|c|c|}
\hline & $\begin{array}{l}\text { Body weight } \\
\text { (g) }\end{array}$ & $\begin{array}{l}\text { Testis weight } \\
(\mathrm{mg})\end{array}$ & $\begin{array}{l}\text { Testis weight } \\
\text { (\% of body weight) }\end{array}$ & $\begin{array}{l}\text { Sperm count } \\
\text { (10 } 10^{6} \text { per epididymis) }\end{array}$ \\
\hline \multicolumn{5}{|l|}{ Geotype } \\
\hline PIASx ${ }^{+/+}$ & $27 \cdot 8 \pm 0 \cdot 7$ & $113 \cdot 7 \pm 2 \cdot 5$ & $0.41 \pm 0.01$ & $9.06 \pm 0.57$ \\
\hline PIASx ${ }^{-/-}$ & $28 \cdot 9 \pm 1 \cdot 2$ & $87 \cdot 9 \pm 4 \cdot 0^{*}$ & $0.31 \pm 0.02^{*}$ & $7.37 \pm 0.88$ \\
\hline
\end{tabular}

${ }^{*} P<0.001$

statistical analyses. Results were normalized to porphobilinogen deaminase (PBGD) by dividing the individual RT-PCR values by the mean of three repeated PBGD test values of the respective sample to reduce variability between RNA amounts introduced into the RT-PCR reactions (Schrader et al. 2002). To distinguish the specific PGR products from non-specific products and primer dimers, a melting-curve analysis was performed as described earlier (Woo et al. 1998). Additionally, samples were analyzed by agarose gel electrophoresis to verify that the amplified products exhibited correct sizes.

\section{Statistical analysis}

Data are presented as means \pm S.E.M. and were analyzed by $t$-test using SPSS version $10 \cdot 0$ statistical software. $P<0 \cdot 05$ was considered as statistically significant.

\section{Results}

\section{Targeted disruption of the PIASx gene}

We have used the gene-trap approach to disrupt the PIASx gene (Wiles et al. 2000, Hansen et al. 2003). The gene-trap vector contains an En-2 splice acceptor site to allow the fusion of the $\beta$ geo fusion gene to the target gene. The murine PIASx gene is located on chromosome 18. It is composed of 15 exons and gives rise to $\alpha$ and $\beta$ forms of PIASx mRNA through alternative splicing of the last three exons. The gene-trap vector insertion occurred in the second intron of the PIASx gene (Fig. 1A). Northern blotting of testicular RNA with a probe that recognizes the second exon of the PIASx gene showed that PIASx ${ }^{+/-}$mice indeed produced an additional longer transcript that is likely to correspond to the fusion of the $5^{\prime}$ part of PIASx transcript and the Bgeo transcript (Fig. 1B). The amount of authentic PIASx mRNA was reduced in $\mathrm{PIASx}^{+/-}$mice. In PIASx $^{-/-}$mice, the authentic PIASx mRNA was totally absent, and the intensity of the longer transcript was stronger than in PIASx ${ }^{+/-}$mice (Fig. 1B). Northern analysis with a probe that recognizes exons downstream of the gene-trap vector insertion site demonstrated that the native PIASx transcript was completely absent in PIASx $^{-/-}$mice, but a shorter form of the PIASx transcript was present in $\mathrm{PIASx}^{+/-}$and PIASx ${ }^{-/-}$ mice (Fig. 1C). Immunoblotting showed a gene-dosedependent disappearance of PIASx-derived signals in testis, and no additional shorter forms of PIASx proteins, which might have been encoded by the shorter form of the PIASx transcript, were evident in $\mathrm{PIASx}^{+/-}$or PIASx $^{-/-}$mice (Fig. 1D).

\section{Testis weight is reduced in PIASx mutant mice}

The PIASx mutant mice did not show any obvious phenotype in the preliminary analysis; the animals were viable, grew normally, and were fertile (Hansen et al. 2003). Since PIASx is highly expressed in Sertoli cells and developing spermatogonia and spermatocytes, it was pertinent to examine testicular function of PIASx mutant mice in more detail. Although the body weights were similar in $\mathrm{PIASx}^{+/+}$and PIASx ${ }^{-/-}$mice, there was a clear difference in the weight of their testes: the absolute and relative testicular weights were decreased by $23 \%(P<0 \cdot 001)$ and $25 \%(P<0 \cdot 001)$, respectively, in homozygote PIASx mutants compared with their wild-type littermates (Table 1). PIASx mutants also exhibited a tendency for diminished production of spermatozoa as their epididymal sperm counts were $19 \%$ lower $(P=0 \cdot 12)$ when compared with wild-type mice (Table 1). However, spermatozoa of PIASx $-1-$ mice were motile, and Acridine Orange staining did not reveal any gross disturbances in the spermatozoa DNA structure (results not shown).

\section{PIASx mutant mice have an increased rate of apoptosis}

Histological examination of testes of 3- and 9-month-old mutant mice revealed no apparent abnormalities in their spermatogenesis (Fig. 2B and C). However, in 3-month-old mutant mice, the average diameter of stage VII-VIII seminiferous tubule was decreased by $6 \%$ $(P=0 \cdot 151$; Fig. 2A), with both seminiferous tubule lumen size and wall thickness being reduced. We next performed TUNEL staining to examine whether PIASx 
A
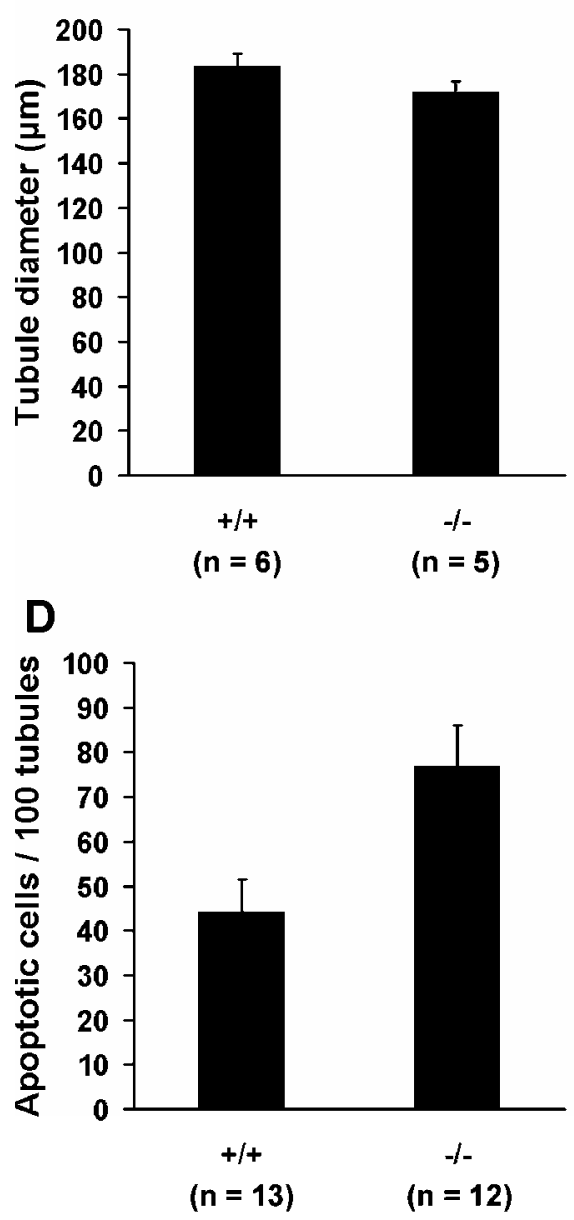

B

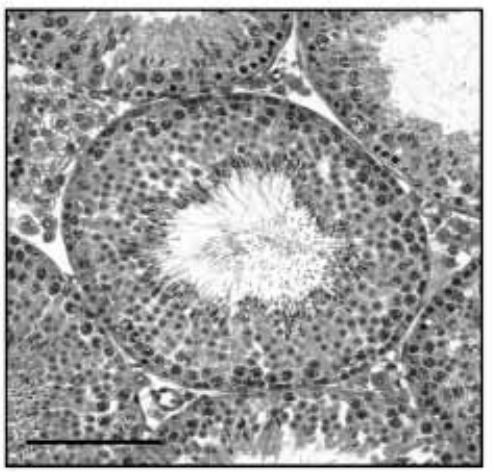

$+1+$

E

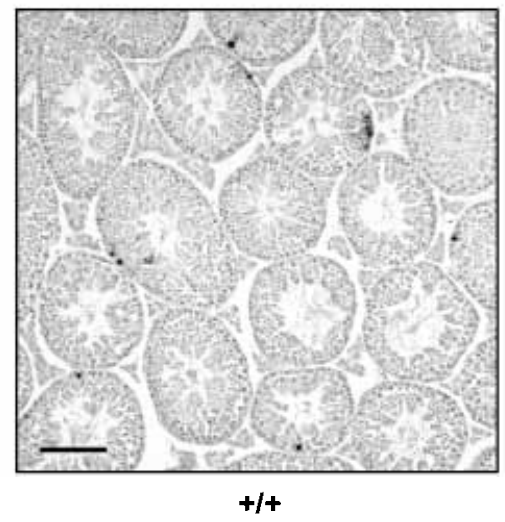

C

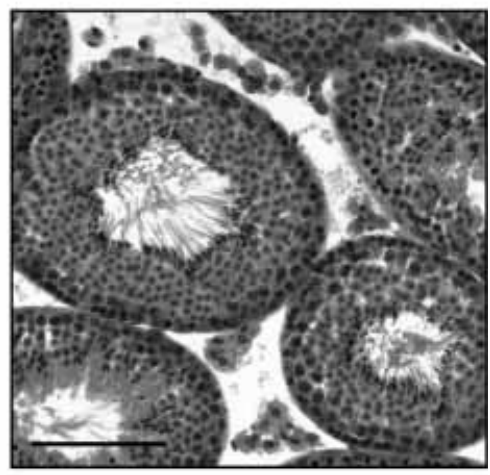

$-1-$

$\mathbf{F}$

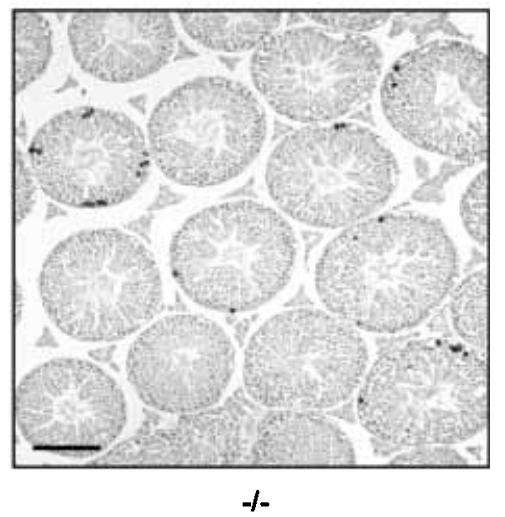

Figure 2 Analysis of tubule diameter and number of TUNEL-positive cells. (A) Diameter of stage VII-VIII tubules was measured with the help of a scale bar. Values in PIASx ${ }^{+/+}$and PIASx ${ }^{-1-}$ mice are presented as means \pm S.E.M. (B, C) Representative hematoxylin and eosin-stained section of PIASx ${ }^{+/+}$and PIASx ${ }^{-/-}$testis, respectively. Scale bar, $100 \mu \mathrm{m}$. (D) Apoptotic cells were visualized with TUNEL staining. Values are the number of TUNEL-positive cells per 100 tubules in PIASx ${ }^{+/+}$and PIASx ${ }^{-/-}$mice. (E, F) Representative TUNEL-stained sections of the wild-type and mutant testis, repectively. Scale bar, $100 \mu \mathrm{m}$.

gene disruption influenced testicular cell apoptosis. We measured the number of TUNEL-positive cells and seminiferous tubules in cross-sectioned testes and observed that the number of apoptotic cells was increased by $74 \%$ $(P<0 \cdot 05)$ in PIASx mutant mice compared with wild-type mice (Fig. 2D). However, the apoptotic cells did not appear to accumulate in any specific step or stage of spermatogenesis (Fig. 2E and F). Most of the TUNELpositive cells were primary spermatocytes both in wild-type and PIASx-knockout mice.

\section{Serum hormones}

Testis is a target tissue of several endocrine hormones. FSH has a stimulatory role in spermatogenesis and LH regulates testosterone production of Leydig cells
(Cooke \& Saunders 2002). Furthermore, testosterone, produced intratesticularly by Leydig cells, is required for normal spermatogenesis. Therefore, we studied serum levels of FSH and LH as well as the intratesticular level of testosterone. As shown in Table 2, we did not find significant differences in the levels of FSH and LH between PIASx ${ }^{+/+}$and PIASx ${ }^{-/-}$mice. However, the intratesticular testosterone concentration was elevated by $67 \%$ in PIASx ${ }^{-1-}$ mice, but the difference was not statistically significant. Even though the trend to intratesticular testosterone is not likely to explain the increased testicular apoptosis, we cannot rule out the possibility that it may have contributed to the reduction of testis weight. A reminiscent situation in humans is testicular atrophy and azoospermia secondary to supraphysiologic androgen levels. 
Table 2 Serum LH, FSH, and testicular testosterone levels of wild-type and mutant male mice

\begin{tabular}{|c|c|c|c|}
\hline & $\begin{array}{l}\text { LH } \\
(\mathrm{ng} / \mathrm{ml})\end{array}$ & $\begin{array}{l}\text { FSH } \\
(\mathrm{ng} / \mathrm{ml})\end{array}$ & $\begin{array}{l}\text { Testosterone } \\
\text { (pg/ } / \mathrm{g} \text { protein) }\end{array}$ \\
\hline \multicolumn{4}{|l|}{ Geotype } \\
\hline $\mathrm{PIASx}^{+/+}$ & $0.46 \pm 0.25(n=12)$ & $27 \cdot 3 \pm 1 \cdot 6(n=8)$ & $0.9 \pm 0.1(n=7)$ \\
\hline PIASx ${ }^{-/-}$ & $0.46 \pm 0.27(n=13)$ & $29 \cdot 8 \pm 1 \cdot 8(n=8)$ & $1.5 \pm 0.4(n=7)$ \\
\hline
\end{tabular}

\section{Expression of mRNAs encoding PIAS1, PIAS3, and PIASy}

PIASx is a member of the PIAS family, raising the possibility that the amounts of other members of the family may increase to compensate for the loss of PIASx. We addressed this issue by examining the levels of mRNAs coding for PIAS1, PIAS3, and PIASy by real-time quantitative RT-PCR and Northern blotting. We did not detect changes in the mRNA levels of PIAS1 or PIAS3, whereas the amount of testicular PIASy mRNA was reduced by $30 \%$ in PIASx $^{-1-}$ mice (Fig. 3).

\section{Gene expression in testis}

Many interaction partners of PIASx, such as AR (androgen receptor) and p53, are transcription factors. Depending on the studied protein and promoter context, overexpressed PIASx can either increase or decrease transcriptional activity of the target protein (Schmidt \& Müller 2003). In order to study the effect of PIASx gene disruption on AR-dependent gene expression, we examined the mRNA level of the Pem gene, whose expression is androgen-regulated and Sertoli-cell-specific (Rao et al. 2003), and found that the amount of Pem mRNA was increased by $\sim 33 \%$ in PIASx ${ }^{-/-}$animals

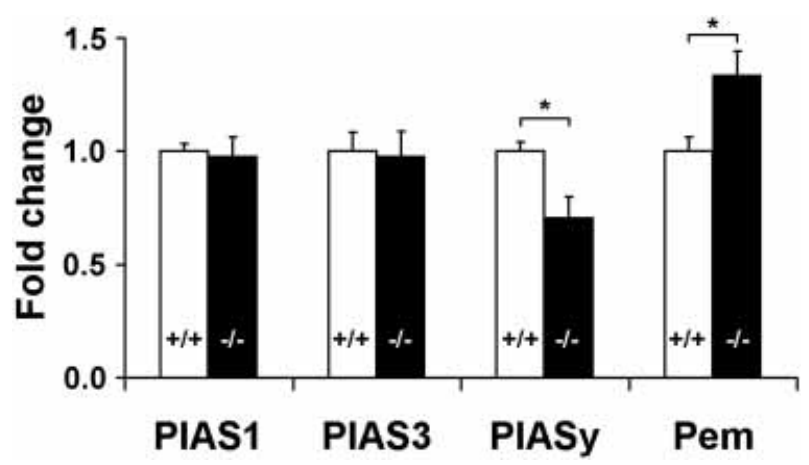

Figure 3 Expression of PIAS1, PIAS3, PIASy, and Pem mRNAs in testes. Real-time quantitative RT-PCR analysis of PIAS and Pem transcripts of PIASx ${ }^{-1-}$ and $\mathrm{PIASx}^{+/+}$mice was performed using total testicular RNA $(3 \mu \mathrm{g})$ from six wild-type mice and seven knockout mice under conditions described in the Materials and methods section. * indicates a statistical difference $(P<0.05)$. compared with wild-type mice (Fig. 3). In order to study the effect of PIASx gene disruption on the transcriptome, we compared testicular mRNAs in PIASx ${ }^{+/+}$and $\mathrm{PIASx}^{-/-}$mice by microarray analysis and found several differentially expressed genes (showing at least 2-fold change; Supplementary data table 2 (see http://jme.endocrinology-journals.org/content/vol34/ issue 3/). However, these genes did not accumulate to any specific functional category. Among the differentially expressed genes that have a possible testicular function, DNA polymerase $\kappa$ (Polk; Unigene Mm.89926) and X-linked zinc-finger protein (Zfx; Mm.919) were upregulated, whereas DEAD box polypeptide 24 (Ddx24; Mm.3935), DNA polymerase $\lambda$ (Poll; Mm.46509), trafficking protein particle complex 2 (Trappc2; Mm.279752), tissue plasminogen activator (Plat; Mm.154660), and growth factor/erv1 (S. cerevisiae)like (Gfer; Mm.28124) were downregulated in the mutant mice. As assessed by quantitative RT-PCR, the Gfer mRNA was decreased by $2 \cdot 4$-fold in PIASx ${ }^{-} /-$ mice compared with PIASx ${ }^{+/+}$mice.

\section{Discussion}

The plausible role of PIASx in spermatogenesis prompted us to study the testicular function of PIASx mutant mice. The main finding in this study was that the mutant mice had reduced testis weight, which was accompanied by a smaller diameter of seminiferous tubules and a lower epididymal sperm count. No gross changes in ovarian size or histology were observed in PIASx-knockout mice, which is in line with the low expression level of the PIASx gene in ovary (Moilanen et al. 1999, Gross et al. 2001). Despite the lower epididymal sperm count, the mutant mice were fertile. This is not surprising, as it is estimated that sperm count should be reduced to $10 \%$ or less to have a clear impact on fertility (Russel et al. 1990). Most of the testis volume is governed by seminiferous tubules and therefore the reduction of seminiferous tubule diameter is likely to be the explanation for the reduced testis size. However, histological examination did not reveal any arrest in spermatogenesis that might explain the smaller diameter of seminiferous tubules in PIASx-deficient mice. Thus, either the number of spermatogonia or the rate of their 
division is disturbed by the lack of PIASx. A similar phenotype has been described in FSH- and ActRIIA (activin receptor IIA)-deficient mice (Matzuk et al. 1995, Kumar et al. 1997). However, FSH- and ActRIIAdeficient mice have greatly diminished serum FSH levels, whereas FSH levels of PIASx-deficient mice were comparable to those in wild-type animals, indicating that the mechanism underlying the reduced number of spermatogenic cells is different in PIASx-deficient mice.

Studies on D. melanogaster, which has only one PIAS gene, have demonstrated clearly the physiological importance of PIAS proteins for multicellular organisms, in that disruption of dPIAS/Zimp/Su(var)2-10 leads to embryonic lethality due to severe abnormalities in chromosome condensation and segregation (Hari et al. 2001). In S. cerevisiae, mutation of either Siz1 or Siz2 fails to cause a striking phenotype, but a strain that harbors mutations in both genes grows poorly at a lower temperature (Johnson \& Gupta 2001). PIASy- and PIAS1-deficient mice were being generated while this paper was being prepared for publication (Liu et al. 2004, Roth et al. 2004, Wong et al. 2004). PIASyknockout mice appear to be phenotypically normal and show protein-sumoylation patterns comparable with those of wild-type mice (Roth et al. 2004, Wong et al. 2004). Interestingly, PIAS $1^{-/-}$mice, especially males, are smaller than the wild-type mice and are born at a frequency lower than the expected Mendelian ratio, but they do not have any histological defects and they are also fertile (Liu et al. 2004). These results, together with the subtle phenotype of PIASx-knockout mice, suggests that functional redundancy is a general phenomenon among PIAS proteins in vivo. In line with this, several in vitro experiments have shown that more than one PIAS protein may promote sumoylation of the same target protein, such as PIAS 1 and PIASx $\beta$ towards p53 (Schmidt \& Müller 2002) and PIASl and PIASxa towards AR (Kotaja et al. 2002, Nishida \& Yasuda 2002). In keeping with this, we did not detect changes in the overall sumoylation pattern of proteins in PIASx mutant mice (data not shown).

PIASx ${ }^{-/-}$mice had qualitatively normal spermatogenesis and were fertile, although their testes were smaller than in wild-type littermates. PIAS1 and PIASy are, however, normally highly expressed in the testis and their expression patterns overlap with that of PIASx, although their highest levels are detected in different cells of the seminiferous epithelium (Tan et al. 2000, 2002, Gross et al. 2001, Yan et al. 2003). Members of the PIAS protein family are known to interact with each other and be capable of modulating each others' functions (Tan et al. 2002). Therefore, the mild phenotype of PIASx ${ }^{-/-}$mice may also, at least in part, be a result of an imbalance among the PIAS proteins in the mutant mice.
The extent of apoptosis was increased in PIASx mutant mice testis, as judged by their higher number of TUNEL-positive cells. This finding is interesting because several sumoylation targets, such as topoisomerase I, NEMO (nuclear factor $\mathrm{\kappa B}$ essential modulator), Smads, and p53, are involved in apoptosis (Gostissa et al. 1999, Rodriguez et al. 1999, Horie et al. 2002, Huang et al. 2003, Lin et al. 2003). Notably, both p53 and Smads are also interaction partners for PIAS proteins (Kahyo et al. 2001, Megidish et al. 2002, Schmidt \& Müller 2002, Lin et al. 2003, Ohshima \& Shimotohno 2003), although the role of PIAS proteins in the regulation of p53 function has remained elusive. Although PIAS1 and PIASx $\beta$ promote sumoylation of $\mathrm{p} 53$, repression of p53 activity by PIAS proteins is not entirely dependent on p53 sumoylation (Schmidt \& Müller 2002). Likewise, PIASy is able to block induction of p53 target genes (Nelson et al. 2001). Other studies have, however, pointed out that PIAS1 and PIAS3 L may in fact activate p53-dependent gene expression (Kahyo et al. 2001, Wible et al. 2002). Smads act as downstream mediators of transforming growth factor $\beta$ and activin signaling and are thus potential regulators of apoptosis. PIAS proteins are capable of facilitating sumoylation of Smads. PIASy tends to decrease transcriptional activity of Smad3 and Smad4 (Lee et al. 2003, Long et al. 2003), whereas PIASx $\beta$ and PIAS3 activate the function of Smad4 and Smad3 respectively (Ohshima \& Shimotohno 2003, Long et al. 2004). Interestingly, PIAS3L and PIAS1 themselves have been demonstrated to possess proapoptotic activities (Liu \& Shuai 2001, Wible et al. 2002). Increased apoptosis in the testis of PIASx-deficient mice suggests that, unlike PIAS1 and PIAS3L, PIASx can act as a negative regulator of apoptosis. The mechanism of increased apoptosis remains to be elucidated, since we could not detect differential expression of apoptosis-related genes in our microarray analysis.

Majority of the reported interaction partners of PIAS proteins are transcription factors (Schmidt \& Müller 2003). Even though PIAS proteins can act as SUMO E3 ligases, all of their functions are not necessarily related to sumoylation (Horie et al. 2002, Schmidt \& Müller 2002). For example, the effects of PIAS proteins on AR activity depend on cell and promoter context and may be either positive or negative (Kotaja et al. 2000). We studied the expression of Pem that is an AR target gene in Sertoli cells and found that the Pem mRNA level was increased in PIASx ${ }^{-1-}$ mice, which is in line with the notion that PIASx-promoted SUMO modification of AR may repress the receptor function in murine testis. Unfortunately, the currently available antibodies do not allow direct measurement of sumoylation of endogenous AR in mice.

In this study, we found Gfer among the genes that were repressed in the testes of PIASx ${ }^{-1-}$ mice. Gfer is 
a sulphydryl oxidase capable of generating disulphide bridges in proteins (Klissenbauer et al. 2002). Gfer accumulates in mitochondria of spermatogonia and primary spermatocytes, indicating that Gfer may be an important protein in the early stages of spermatogenesis (Klissenbauer et al. 2002). Interestingly, Gfer has been found to augment liver regeneration and enhance the success rate of pancreatic transplantation, potentially by regulating intracellular redox status (Hagiya et al. 1994, Adams et al. 1998, Wu et al. 2003). However, the function of Gfer in context of spermatogenesis and its possible role in apoptosis need further studies.

In conclusion, we show that PIASx $^{-/}$mice produce viable spermatozoa. This finding indicates that PIASx is not absolutely required for the spermatogenesis, and the deficiency of PIASx may be substituted by other PIAS proteins. However, the increased number of apoptotic spermatogenic cells, the reduced epididymal sperm count and diameter of seminiferous tubules indicates mildly disturbed spermatogenesis, implying that spermatogenesis is quantitatively rather than qualitatively dependent on functional PIASx.

\section{Acknowledgements}

We thank Ms Katja Kiviniemi for excellent technical assistance and the personnel of the animal facility for taking care of the mice. This work was supported by grants from the Academy of Finland, Biocentrum Helsinki, Finnish Foundation for Cancer Research, Finnish Medical Foundation, Helsinki University Central Hospital, Research and Science Foundation of Farmos, and Sigrid Jusélius Foundation. The authors declare that there is no conflict of interest that would prejudice the impartiality of this scientific work.

\section{References}

Adams GA, Maestri M, Squiers EC, Alfrey EJ, Starzl TE \& Dafoe DG 1998 Augmenter of liver regeneration enhances the success rate of fetal pancreas transplantation in rodents. Transplantation 65 32-36.

Betz A, Lampen N, Martinek S, Young MW \& Darnell JE Jr 2001 A Drosophila PIAS homologue negatively regulates stat92E. PNAS 98 9563-9568.

Bradford MM 1976 A rapid and sensitive method for the quantitation of microgram qualities of protein utilizing the principle of protein-dye binding. Analytical Biochemistry 72 248-254.

Chung CD, Liao J, Liu B, Rao X, Jay P, Berta P \& Shuai K 1997 Specific inhibition of Stat3 signal transduction by PIAS3. Science 278 1803-1805.

Cooke HJ \& Saunders PT 2002 Mouse models of male infertility. Nature Reviews Genetics 3 790-801.

Desterro JM, Rodriguez MS \& Hay RT 1998 SUMO-1 modification of IkappaBalpha inhibits NF-kappaB activation. Molecular Cell $\mathbf{2}$ 233-239.

Gostissa M, Hengstermann A, Fogal V, Sandy P, Schwarz SE, Scheffner M \& Del Sal G 1999 Activation of p53 by conjugation to the ubiquitin-like protein SUMO-1. EMBO Fournal 18 6462-6471.
Gross M, Liu B, Tan J, French FS, Carey M \& Shuai K 2001 Distinct effects of PIAS proteins on androgen-mediated gene activation in prostate cancer cells. Oncogene 20 3880-3887.

Haavisto AM, Pettersson K, Bergendahl M, Perheentupa A, Roser JF \& Huhtaniemi I 1993 A supersensitive immunofluorometric assay for rat luteinizing hormone. Endocrinology 132 1687-1691.

Hagiya M, Francavilla A, Polimeno L, Ihara I, Sakai H, Seki T, Shimonishi M, Porter KA \& Starzl TE 1994 Cloning and sequence analysis of the rat augmenter of liver regeneration (ALR) gene: expression of biologically active recombinant ALR and demonstration of tissue distribution. PNAS $918142-8146$.

Hansen J, Floss T, Van Sloun P, Fuchtbauer EM, Vauti F, Arnold HH, Schnütgen F, Wurst W, von Melchner H \& Ruiz P 2003 A large-scale, gene-driven mutagenesis approach for the functional analysis of the mouse genome. PNAS 100 9918-9922.

Hari KL, Cook KR \& Karpen GH 2001 The Drosophila Su(var)2-10 locus regulates chromosome structure and function and encodes a member of the PIAS protein family. Genes et Development 15 1334-1348.

Hoege C, Pfander B, Moldovan GL, Pyrowolakis G \& Jentsch S 2002 RAD6-dependent DNA repair is linked to modification of PGNA by ubiquitin and SUMO. Nature 419 135-141.

Horie K, Tomida A, Sugimoto Y, Yasugi T, Yoshikawa H, Taketani Y \& Tsuruo T 2002 SUMO-1 conjugation to intact DNA topoisomerase I amplifies cleavable complex formation induced by camptothecin. Oncogene 21 7913-7922.

Huang TT, Wuerzberger-Davis SM, Wu ZH \& Miyamoto S 2003 Sequential modification of NEMO/IKKgamma by SUMO-1 and ubiquitin mediates NF-kappaB activation by genotoxic stress. Cell $115565-576$.

Huhtaniemi IT, Nikula H \& Ranniko S 1985 Treatment of prostatic patients with a gonadotropin-releasing hormone agonist analog: acute and long term effects on endocrine functions of the testes. Fournal of Clinical Endocrinology and Metabolism 61 698-704.

Johnson ES \& Gupta AA 2001 An E3-like factor that promotes SUMO conjugation to the yeast septins. Cell 106 735-744.

Kagey MH, Melhuish TA \& Wotton D 2003 The polycomb protein Pc2 is a SUMO E3. Cell $113127-137$.

Kahyo T, Nishida T \& Yasuda H 2001 Involvement of PIAS1 in the sumoylation of tumor suppressor p53. Molecular Cell 8 713-718.

Klissenbauer M, Winters S, Heinlein UA \& Lisowsky T 2002 Accumulation of the mitochondrial form of the sulphydryl oxidase Ervlp/Alrp during the early stages of spermatogenesis. Fournal of Experimental Biology 205 1979-1986.

Kotaja N, Aittomäki S, Silvennoinen O, Palvimo JJ \& Jänne OA 2000 ARIP3 (androgen receptor-interacting protein 3) and other PIAS (protein inhibitor of activated STAT) proteins differ in their ability to modulate steroid receptor-dependent transcriptional activation. Molecular Endocrinology 14 1986-2000.

Kotaja N, Karvonen U, Jänne OA \& Palvimo JJ 2002 PIAS proteins modulate transcription factors by functioning as SUMO-1 ligases. Molecular and Cellular Biology 22 5222-5234.

Kumar TR, Wang Y, Lu N \& Matzuk MM 1997 Follicle stimulating hormone is required for ovarian follicle maturation but not male fertility. Nature Genetics 15 201-204.

Lee PS, Chang C, Liu D \& Derynck R 2003 Sumoylation of Smad4, the common Smad mediator of transforming growth factor-beta family signaling. Fournal of Biological Chemistry 278 27853-27863.

Lin X, Liang M, Liang YY, Brunicardi FC, Melchior F \& Feng XH 2003 Activation of transforming growth factor-beta signaling by SUMO-1 modification of tumor suppressor Smad4/DPC4. Fournal of Biological Chemistry 278 18714-18719.

Liu B \& Shuai K 2001 Induction of apoptosis by protein inhibitor of activated Statl through c-Jun NH2-terminal kinase activation. Fournal of Biological Chemistry 276 36624-36631.

Liu B, Mink S, Wong KA, Stein N, Getman C, Dempsey PW, Wu H \& Shuai K 2004 PIASl selectively inhibits interferon-inducible 
genes and is important in innate immunity. Nature Immunology $\mathbf{5}$ 891-898.

Long J, Matsuura I, He D, Wang G, Shuai K \& Liu F 2003 Repression of Smad transcriptional activity by PIASy, an inhibitor of activated STAT. PNAS $\mathbf{1 0 0} 9791-9796$.

Long J, Wang G, Matsuura I, He D \& Liu F 2004 Activation of Smad transcriptional activity by protein inhibitor of activated STAT3 (PIAS3). PNAS 101 99-104.

Matzuk MM, Kumar TR \& Bradley A 1995 Different phenotypes for mice deficient in either activins or activin receptor type II. Nature 374 356-360.

Megidish T, Xu JH \& Xu CW 2002 Activation of p53 by protein inhibitor of activated Statl (PIAS1). Journal of Biological Chemistry 277 8255-8259.

Melchior F, Schergaut M \& Pichler A 2003 SUMO: ligases, isopeptidases and nuclear pores. Trends in Biochemical Sciences $\mathbf{2 8}$ 612-618.

Mohr SE \& Boswell RE 1999 Zimp encodes a homologue of mouse Mizl and PIAS3 and is an essential gene in Drosophila melanogaster. Gene 229 109-116.

Moilanen AM, Karvonen U, Poukka H, Yan W, Toppari J, Jänne OA \& Palvimo JJ 1999 A testis-specific androgen receptor coregulator that belongs to a novel family of nuclear proteins. Fournal of Biological Chemistry 274 3700-3704.

Nakagawa K \& Yokosawa H 2002 PIAS3 induces SUMO-1 modification and transcriptional repression of IRF-1. FEBS Letters 530 204-208.

Nelson V, Davis GE \& Maxwell SA 2001 A putative protein inhibitor of activated STAT (PIASy) interacts with p53 and inhibits p53-mediated transactivation but not apoptosis. Apoptosis 6 221-234.

Nishida T \& Yasuda H 2002 PIAS1 and PIASxalpha function as SUMO-E3 ligases toward androgen receptor and repress androgen receptor-dependent transcription. Fournal of Biological Chemistry 277 41311-41317.

Ohshima T \& Shimotohno K 2003 Transforming growth factor-beta-mediated signaling via the p38 MAP kinase pathway activates Smad-dependent transcription through SUMO-1 modification of Smad4. Fournal of Biological Chemistry 278 50833-50842.

Pichler A, Gast A, Seeler JS, Dejean A \& Melchior F 2002 The nucleoporin RanBP2 has SUMO1 E3 ligase activity. Cell 108 109-120.

Rao MK, Wayne CM, Meistrich ML \& Wilkinson MF 2003 Pem homeobox gene promoter sequences that direct transcription in a Sertoli cell-specific, stage-specific, and androgen-dependent manner in the testis in vivo. Molecular Endocrinology 17 223-233.

Rodriguez MS, Desterro JM, Lain S, Midgley CA, Lane DP \& Hay RT 1999 SUMO-1 modification activates the transcriptional response of p53. EMBO Fournal $\mathbf{1 8}$ 6455-6461.

Roth W, Sustmann C, Kieslinger M, Gilmozzi A, Irmer D, Kremmer E, Turck C \& Grosschedl R 2004 PIASy-deficient mice display modest defects in IFN and Wnt signaling. Fournal of Immunology 173 6189-6199.

Russel LD, Ettlin RA, SinhaHikim AP \& Clegg ED 1990 Histopathology of the testis. Quantitative evaluation of testis histopathology. In Histological and histopathological evaluation of the testis, pp 254 -264. Eds Russel LD, Ettlin RA, SinhaHikim AP \& Clegg ED. Clearwater: Cache River Press.

Schmidt D \& Müller S 2002 Members of the PIAS family act as SUMO ligases for c-Jun and p53 and repress p53 activity. PNAS $992872-2877$.
Schmidt D \& Müller S 2003 PIAS/SUMO: new partners in transcriptional regulation. Cellular and Molecular Life Sciences $\mathbf{6 0}$ 2561-2574.

Schrader M, Müller M, Schulze W, Heicappell R, Krause H, Straub B \& Miller K 2002 Quantification of telomerase activity, porphobilinogen deaminase and human telomerase reverse transcriptase mRNA in testicular tissue - new parameters for a molecular diagnostic classification of spermatogenesis disorders. International Fournal of Andrology $2534-44$.

Seeler JS \& Dejean A 2003 Nuclear and unclear functions of SUMO. Nature Reviewes in Molecular Cell Biology 4 690-699.

Tan J, Hall SH, Hamil KG, Grossman G, Petrusz P, Liao J, Shuai K \& French FS 2000 Protein inhibitor of activated STAT-1 (signal transducer and activator of transcription-1) is a nuclear receptor coregulator expressed in human testis. Molecular Endocrinology 14 14-26.

Tan JA, Hall SH, Hamil KG, Grossman G, Petrusz P \& French FS 2002 Protein inhibitors of activated STAT resemble scaffold attachment factors and function as interacting nuclear receptor coregulators. Fournal of Biological Chemistry 277 16993-17001.

van Casteren JI, Schoonen WG \& Kloosterboer HJ 2000 Development of time-resolved immunofluorometric assays for rat follicle-stimulating hormone and luteinizing hormone and application on sera of cycling rats. Biology of Reproduction $\mathbf{6 2}$ 886-894.

Verger A, Perdomo J \& Crossley M 2003 Modification with SUMO A role in transcriptional regulation. EMBO Reports 4 137-142.

Wible BA, Wang L, Kuryshev YA, Basu A, Haldar S \& Brown AM 2002 Increased $\mathrm{K}^{+}$efflux and apoptosis induced by the potassium channel modulatory protein KChAP/PIAS3 beta in prostate cancer cells. Fournal of Biological Chemistry 277 $17852-17862$.

Wiles MV, Vauti F, Otte J, Füchtbauer EM, Ruiz P, Füchtbauer A, Arnold HH, Lehrach H, Metz T, von Melchner H \& Wurst W 2000 Establishment of a gene-trap sequence tag library to generate mutant mice from embryonic stem cells. Nature Genetics 24 13-14.

Wittwer CT, Ririe KM, Andrew RV, David DA, Gundry RA \& Balis UJ 1997 The Lightcycler: a microvolume multisample fluorimeter with rapid temperature control. Biotechniques 22 176-181.

Wong KA, Kim R, Christofk H, Gao J, Lawson G \& Wu H 2004 Protein inhibitor of activated STAT Y (PIASy) and a splice variant lacking exon 6 enhance sumoylation but are not essential for embryogenesis and adult life. Molecular and Cellular Biology 24 $5577-5586$.

Woo THS, Patel BKC, Cinco M, Smythe LD, Symonds ML, Norris MA \& Dohnt MF 1998 Real-time homogeneous assay of rapid cycle polymerase chain reaction product for identification of Leptonema illini. Analytical Biochemistry 259 112-117.

Wu GK, Dailey TA, Dailey HA, Wang BC \& Rose JP 2003 The crystal structure of augmenter of liver regeneration: A mammalian FAD-dependent sulfhydryl oxidase. Protein Science 12 $1109-1118$.

Yan W, Santti H, Jä nne OA, Palvimo JJ \& Toppari J 2003 Expression of the E3 SUMO-1 ligases PIASx and PIAS1 during spermatogenesis in the rat. Gene Expression Patterns $\mathbf{3}$ 301-308.

Received 30 November 2004 Accepted 25 January 2005 